\title{
Phytochemical Investigation and Pharmacological Evaluation of Solanum xanthocarpum Endowed with their potential Activity
}

\author{
MAHAVIR CHHAJED*1, ATIKA JAIN ${ }^{2}$, SOURABH GUPTA ${ }^{3}$, ISHAN \\ DUBEY ${ }^{4}$ AND A. K. SHRIVASTAVA ${ }^{5}$ \\ ${ }^{1}$ Indore Institute of Pharmacy, Rau, Indore, MP - 453331, India \\ ${ }^{2}$ Dr. APJ Abdul Kalam University, Indore, MP, India \\ ${ }^{3}$ Chitkara University, Rajpura, Punjab, India \\ ${ }^{4}$ Shri Aurobindo Institute of Pharmacy, Indore, MP, India \\ ${ }^{5}$ Nandini Nagar Mahavidyalaya, UP, India \\ *Email: chhajed.mahavir@gmail.com
}

Received: January 07, 2018 I Revised: March 01, 2018 | Accepted: April 7, 2018

Published online: May 02, 2018

The Author(s) 2018. This article is published with open access at www.chitkara.edu.in/publications

\begin{abstract}
The study was done to assess the in-vitro antibacterial potential of various extracts was studied and compared with ciprofloxacin as the standard and shows significant action against E. coli, B. substilis $S$. aureus, S. pyrogenes, $P$. aeruginosa, and $S$. typhi. Anti-fungal potential of the aqueous extract also studied using miconazole as standard and shows significant action against $A$. niger and $C$. albicans. Anthelmintic potential of the aqueous and ethanolic extracts was also studied on earthworms, Eudrillus eugeniae using albendazole as standard and shows moderate activity. In the present study in-vitro free radical scavenging activity of whole plant material performed. Various crude extracts of $S$. xanthocarpum was prepared by successive maceration process using various solvents such as; chloroform, petroleum ether $\left(60-80^{\circ}\right)$, acetone, ethanol and distilled water. Each one extract have been chosen to study the free radical inhibitory activity by DPPH radical scavenging method. The preliminary phytochemical screening of extracts showed that sterols, alkaloids, glycosides, tannins, saponins, phenolic compounds, carbohydrates and proteins were present in the plant. Petroleum ether, chloroform, acetone, ethanol and distilled water extracts showed 52.69, 46.15, 21.08, 52.72 and $44.35 \%$ respectively compared to standard ascorbic acid. Acetone extract showed poor inhibition of DPPH radical compared to standard and other extracts also.
\end{abstract}

ournal of Pharmaceutical Technology, Research and Management Vol-6, No-1, May 2018 pp. 55-65 
Chhajed, M

Jain, A

Gupta, S

Dubey, I

Shrivastava, AK
Keywords: S. xanthocarpum, antibacterial, antifungal, DPPH free radical, phytochemical screening.

\section{INTRODUCTION}

Solanum xanthocarpum Schrad and Wendl is significant remedial plant belong to family Solanaceae, which finds uses in Ayurvedic system of medicine such as respiratory tract infection, asthma, cough, common cold, antipyretic, dyspnea, dropsy, and chest pain. ${ }^{1-3}$ The roots are used in fever, cough, asthma, inflammation and as diuretic \& antiemetic. ${ }^{4-6}$ Chronic cough in children relieves if the powdered fruit is given with honey. S. xanthocarpum fruits juice is used in treatment of sore throats and the burning seeds vapours relieves toothache. ${ }^{7}$ The fruit extract is also showed the antispermatogenic action in rats. ${ }^{8-9}$ It also been reported that fruits and roots of the plant exhibit larvicidal activity aligned with tracks of malaria and dengue. ${ }^{10}$

It is usually called as kanthkari and kateli. It's occurs commonly in waste places, roadsides and along railway lines through out India. It is very spiny, diffused much -branched, perpetual plant attaining height up to $1.2 \mathrm{~m}$. The leaves are light green in color and having purplish hairs on both surfaces, ovate or elliptic, sinuate or sub-pinnatified; spines are $1 \mathrm{~cm}$ long, sharp, straight and yellow; flowers violet in lateral cymes; berries green in color with whitish patches when young, yellow and glabrous with greenish white veins, 1.2 to $2 \mathrm{~cm}$ in diameter; seeds glabrous; roots are $3-5 \mathrm{~cm}$ long and $1.5-6 \mathrm{~mm}$ thick, dreary grayish with a spongy fibrous splinter stem, flowers and fruits are bitter and carminative., ${ }^{911-13}$

The growing interest in herb and offer economical uses of plant is part of the movement towards "greener" economics and life styles. ${ }^{14}$ Medicinal plants have fascinated concentration of not only medicine professionals of assorted systems, but also the scientific societies belong to diverse disciplines. Herbal medicines, generally consider not detrimental in given set doses, are turning into trendy throughout the world and WHO presently persuade, counsel and endorse enclosure of these remedies in nationwide health care programme. ${ }^{15}$ In current time, there has been an enormous awareness in herbal medication for the management of number of diseases.

Presently there has been an augmented interest worldwide to recognize antioxidant composite that are therapeutically strongly effective and have stumpy or lack of adverse effects to be used in prophylactic medication. As plants manufacture considerable quantity of antioxidants to avoid the oxidative stress originated by photons and oxygen, it represents a impending resource of innovative compounds with antioxidant potential.

Bearing in mind the mounting attention in evaluating the antioxidant capability of herbal drugs in this research, we studied the antioxidant 
properties of $S$. xanthocarpum. ${ }^{16}$ Medicinal plants are assured source of drugs. $S$ xanthocarpum is a widely available plant in India and very less work has been published so far on antimicrobial viz antibacterial and antifungal, anthelmintic and antioxidant activity. The current research work deals with aforesaid activity of the $S$. xanthocarpum using standard laboratory model.

\section{MATERIAL AND METHODS CHEMICAL AND REAGENTS}

Ciprofloxacin, miconazole and albendazole was received as a gift sample from IPCA Laboratories, Mumbai, India,. Nutrient agar, Sabourd's agar medium and ascorbic acid were purchased from Loba Chem, Mumbai, India. DPPH was purchased from Merck Lab. Mumbai, India. All other reagents and chemical were analytical grade and used as procured.

\subsection{Collection of Plant Material and Preparation of Extract}

The whole plant material was collected in month of March 2005 from Chennai and shade dried. The plant material was authenticated by Dr. P. Jayaraman, Director, Plant Anatomy Research Centre (PARC), Chennai. The taxonomic identification was carried out following Keshavamurthy and Yoganarasimhan (1990) and Gamble(1967). ${ }^{17-18}$

Shade dried, powdered plant material was extracted in close vessel by maceration process for $72 \mathrm{~h}$ at room temperature using petroleum ether (60$80^{\circ}$ ), chloroform, acetone, ethanol and distilled water (contains $0.25 \% \mathrm{v} / \mathrm{v}$ chloroform as preservative). Distillation process under reduced pressure to get solid mass (i.e. completely free from the solvent) was employed to get the extract concentrate. The extractive value was found to be $12.36 \%$ (petroleum ether), $11.61 \%$ (chloroform), 8.98\% (acetone), 8.29\% (ethanol) and 9.48\% (distilled water) with respect to the dry starting powdered plant material. These extracts were subjected for phytochemical evaluation.

\subsection{Micro-organisms}

Six clinical strains Escherichia coli, Bacillus substilis Staphylococcus aureus, Streptococcus pyrogenes, Pseudomonas aeruginosa, and Salmonella typhi were used for evaluating the antibacterial potential against standard ciprofloxacin $(10 \mu \mathrm{g} / \mathrm{mL})$. Two fungal strains Aspergillus niger and Candida albicans were used for antifungal activity determination using Miconazole $(10 \mu \mathrm{g} / \mathrm{mL})$. Earthworms- Eudrillus eugeniae were used for assessment of anthelmintic activity using standard albendazole $(25,50,100 \mathrm{mg} / \mathrm{mL})$. All the microorganisms were obtained from Rajiv Gandhi Vikas Biotechnology Centre, LIT Campus, RTM Nagpur University, Nagpur. Earthworms
Phytochemical Investigation and Pharmacological Evaluation of Solanum xanthocarpum Endowed with their potential Activity

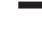


Chhajed, M

Jain, A

Gupta, S

Dubey, I

Shrivastava, AK

were obtained from Horticulture Department, Panjabrao Deshmukh Krishi Vidhyapith, Nagpur. The cultures were checked for their purity by conformist cultural, morphological and biochemical methods. The obtained bacterial and fungal cultures were upholded and hoard in nutrient agar and Sabouraud's agar medium respectively at $4^{\circ} \mathrm{C}$.

\subsection{Antimicrobial Activity}

The agar cup-plate method was employed to assess the antimicrobial activity of the prepared extracts. Nutrient agar and Sabourd's agar medium was employed as growth medium for bacterial and fungal strain respectively. Control experiment was performed in the identical condition by employing ciprofloxacin $(10 \mu \mathrm{g} / \mathrm{mL})$ and miconazole $(10 \mu \mathrm{g} / \mathrm{mL})$ as standard for antibacterial and antifungal activity respectively. The inoculated bacterial and fungal strains were incubated at $37 \pm 2^{\circ} \mathrm{C}$ for $24 \mathrm{hrs}$ and $27 \pm 2^{\circ} \mathrm{C}$ for $48 \mathrm{hrs}$ respectively. ${ }^{19}$ The evaluation of activity against microbial growth was based on the measurement of diameter of zone of inhibition formed by the plant material extract in dimethyl sulphoxide (DMSO) and standard drugs also.

\subsection{Anthelmintic Activity}

The anthelmintic activity of $S$. xanthocarpum was determined by the method of Gunasekaran (2006).$^{20}$ The anthelmintic potential was assessed on adult Indian earthworm - Eudrillus engeniae. Three groups of just about equal size worm comprisinging of six worms in every cluster were relieved in $50 \mathrm{~mL}$ of preferred formulation. Further all group was treated with one of the following- control vehicle ( $1 \%$ gum acacia in normal saline), ethanolic and aqueous extracts of diverse concentrations $(25,50,100 \mathrm{mg} / \mathrm{mL})$ and albendazole $(25,50,100 \mathrm{mg} / \mathrm{mL})$

\subsection{DPPH Radical Scavenging Activity}

Free radical wiping potential of every one extracts were assessed for their in vitro free radical scavenging activities by DPPH radical assay procedure..$^{21}$

A process foundation on the reduction of the coloured DPPH radical solution in methanol has been used to assess the free radical scavenging activity. DPPH reagent $50 \mu \mathrm{L}$ (conc $2 \mathrm{mg} / \mathrm{mL}$ ) have been added to test tubes having $3 \mathrm{~mL}$ of methyl alcohol and the preliminary absorbance measured on UV-Visible spectrophotometer. To the aforesaid test tubes, different test solutions of extract in methanol $(1 \mathrm{mg} / \mathrm{mL})$ have been added $(10-50 \mu \mathrm{L})$. Further ascorbic acid $(0.5 \mathrm{mg} / \mathrm{mL})$ have also been added in the range of 10 $50 \mu \mathrm{L}$ and set aside. Following 20 minutes, absorbance has been measured at $516 \mathrm{~nm}$. The experimental procedures were carried out in triplicate. The 
percentage of reduction in absorbance was calculated from the initial and final absorbance of each tested solution. ${ }^{21-22}$ Percentage of DPPH radical scavenging was assessed using following formula,

$$
\% \text { DPPH Radical Scavenging }=\frac{\text { control }- \text { Test }}{\text { Control }} \times 100
$$

\section{RESULTS}

\subsection{Phytochemical Investigation}

The phytochemical screening of extracts showed the incidence of sterols, alkaloids, glycosides, tannins, saponins, phenolic and flavonoid compounds, carbohydrates and proteins within the plant, amongst them sterols and phenolic compounds may responsible for the antioxidant activities. TLC also reveals that alkaloids, glycosides, sterols, saponin and phenolic compounds are present in $S$. xanthocarpum. The results are reported in table 1 .

Table 1: Phytochemical Screening of Solanum xanthocarpum.

\begin{tabular}{ccccccc}
\hline Extract & Tannin & Glycoside & Sterols & Alkaloids & Saponin & $\begin{array}{c}\text { Reducing } \\
\text { sugar }\end{array}$ \\
\hline Aqueous & + & + & - & + & + & + \\
Ethanolic & + & + & + & + & + & + \\
Acetone & - & + & + & + & + & + \\
Chloroform & - & + & + & + & - & + \\
Petroleum ether & - & - & + & + & - & + \\
\hline
\end{tabular}

\subsection{Antimicrobial activity}

The diameter of zone of inhibition is shown in Table 2. Activity index ${ }^{23}$ was also calculated and reported in the Table 2. The control (DMSO) showed no inhibition of growth while all the extracts were exhibited activity against bacteria and fungus, when compared to ciprofloxacin and miconazole respectively.

\subsection{Anthelmintic activity}

Anthelmintic activity of ethanolic and aqueous extracts of $S$. xanthocarpum against earthworm - Eudrillus eugeniae is shown in Table 3. Ethanolic extract
Phytochemical Investigation and Pharmacological Evaluation of Solanum xanthocarpum Endowed with their potential Activity

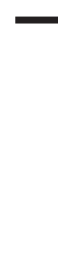

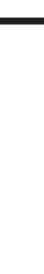


Chhajed, M

Jain, A

Gupta, S

Dubey, I

Shrivastava, AK
Table 2: Antimicrobial Activity of Solanum xanthocarpum Sehrad. \& Wendl.

\begin{tabular}{|c|c|c|c|c|c|c|c|c|c|}
\hline \multirow{3}{*}{ Extract } & \multirow{3}{*}{ Conc } & \multicolumn{8}{|c|}{$\begin{array}{l}\text { Diameter of Zone of Inhibition in mma } \\
\text { (Activity index) b }\end{array}$} \\
\hline & & \multicolumn{6}{|c|}{ Bacteria } & \multicolumn{2}{|c|}{ Fungus } \\
\hline & & E. coli & $\begin{array}{c}\text { B. } \\
\text { substilis }\end{array}$ & S. aureus & $\begin{array}{c}S . \\
\text { pyrogenes }\end{array}$ & $\begin{array}{c}P . \\
\text { aeruginosa }\end{array}$ & S. typhi & A. niger & $\begin{array}{c}C . \\
\text { albicans }\end{array}$ \\
\hline $\begin{array}{l}\text { Petroleum } \\
\text { ether }\end{array}$ & $\begin{array}{c}100 \\
\mathrm{mg} / \mathrm{mL}\end{array}$ & $\begin{array}{c}17 \pm \\
.0 .76 \\
(0.68)\end{array}$ & $\begin{array}{l}21 \pm 0.901 \\
\quad(0.78)\end{array}$ & $\begin{array}{l}19 \pm 0.95 \\
(0.70)\end{array}$ & $\begin{array}{l}12 \pm 1.09 \\
(0.50)\end{array}$ & $\begin{array}{l}11 \pm 0.90 \\
\quad(0.42)\end{array}$ & $\begin{array}{l}19 \pm 0.91 \\
(0.68)\end{array}$ & $\begin{array}{l}10 \pm 0.631 \\
(0.53)\end{array}$ & $\begin{array}{l}11 \pm 1.33 \\
(0.61)\end{array}$ \\
\hline Chloroform & $\begin{array}{c}100 \\
\mathrm{mg} / \mathrm{mL}\end{array}$ & $\begin{array}{l}15 \pm 1.44 \\
\quad(0.6)\end{array}$ & $\begin{array}{l}415 \pm 1.321 \\
\quad(0.56)\end{array}$ & $\begin{array}{l}18 \pm 1.34 \\
(0.67)\end{array}$ & $\begin{array}{l}13 \pm 1.32 \\
(0.54)\end{array}$ & $\begin{array}{l}11 \pm 1.24 \\
(0.42)\end{array}$ & $\begin{array}{l}21 \pm 0.74 \\
(0.75)\end{array}$ & $\begin{array}{l}16 \pm 0.881 \\
\quad(0.84)\end{array}$ & $\begin{array}{l}15 \pm .093 \\
(0.83)\end{array}$ \\
\hline Acetone & $\begin{array}{c}100 \\
\mathrm{mg} / \mathrm{mL}\end{array}$ & $\begin{array}{c}16 \pm 1.13 \\
(0.64)\end{array}$ & $\begin{array}{l}318 \pm 0.862 \\
\quad(0.67)\end{array}$ & $\begin{array}{l}21 \pm 0.74 \\
(0.78)\end{array}$ & $\begin{array}{l}15 \pm 1.54 \\
(0.63)\end{array}$ & $\begin{array}{l}12 \pm 1.24 \\
\quad(0.46)\end{array}$ & $\begin{array}{c}20.5 \pm \\
0.88 \\
(0.73)\end{array}$ & $\begin{array}{c}12 \pm 0.951 \\
(0.63)\end{array}$ & $\begin{array}{l}10 \pm 0.96 \\
\quad(0.56)\end{array}$ \\
\hline Ethanol & $\begin{array}{c}100 \\
\mathrm{mg} / \mathrm{mL}\end{array}$ & $\begin{array}{l}20 \pm 1.01 \\
\quad(0.8)\end{array}$ & $\begin{array}{l}124 \pm 0.892 \\
\quad(0.89)\end{array}$ & $\begin{array}{c}23 \pm 1.12 \\
(0.85)\end{array}$ & $\begin{array}{c}12 \pm 0.99 \\
(0.50)\end{array}$ & $\begin{array}{c}14 \pm 0.94 \\
\quad(0.54)\end{array}$ & $\begin{array}{c}22 \pm 1.51 \\
(0.79)\end{array}$ & $\begin{array}{c}14 \pm 1.441 \\
(0.74)\end{array}$ & $\begin{array}{c}13 \pm 1.02 \\
(0.72)\end{array}$ \\
\hline $\begin{array}{l}\text { Distilled } \\
\text { water }\end{array}$ & $\begin{array}{c}100 \\
\mathrm{mg} / \mathrm{mL}\end{array}$ & $\begin{array}{c}14 \pm 0.87 \\
(0.56)\end{array}$ & $\begin{array}{c}716 \pm 0.991 \\
(0.59)\end{array}$ & $\begin{array}{c}17 \pm 0.76 \\
(0.63)\end{array}$ & $\begin{array}{c}11 \pm 0.80 \\
(0.46)\end{array}$ & $\begin{array}{c}10 \pm 1.08 \\
(0.38)\end{array}$ & $\begin{array}{c}23 \pm 1.28 \\
(0.82)\end{array}$ & $\begin{array}{c}314 \pm 1.291 \\
(0.74)\end{array}$ & $\begin{array}{c}14 \pm 0.68 \\
(0.78)\end{array}$ \\
\hline Ciprofloxacin & $\begin{array}{c}10 \mu \mathrm{g} / \\
\mathrm{mL}\end{array}$ & $25 \pm 0.91$ & $127 \pm 1.442$ & $27 \pm 0.69$ & $24 \pm 1.53$ & $26 \pm 1.32$ & $28 \pm 1.17$ & NA & NA \\
\hline Miconazole & $\begin{array}{c}10 \mu \mathrm{g} / \\
\mathrm{mL}\end{array}$ & NA & NA & NA & NA & NA & NA & $19 \pm 0.73$ & $18 \pm 1.11$ \\
\hline
\end{tabular}

shows significant activity over aqueous extract when compared to standard drug albendazole in same concentration.

\subsection{Free radical scavenging activity}

Ethanolic extract of S. xanthocarpum had showed $50.73 \%$ inhibition of DPPH radical, which is $52.72 \%$ free radical scavenging activity compared to standard, ascorbic acid. Petroleum ether extract also showed almost similar activity (52.69\% compared to standard), while chloroform and aqueous extracts showed 46.15 and $44.35 \%$ scavenging activity respectively compared to standard whereas acetone extract showed poor inhibition of DPPH radical $(21.08 \%)$ compared to standard and other extracts. The results are reported in Table $4 . \mathrm{IC}_{50}$ value for each extract and standard has been calculated and linear regression curve for $\log$ value of $\mathrm{IC}_{50}$ is established and revealed in figure I. 
Table 3: Anthelmintic Activity of Solanum xanthocarpum Sehrad. \& Wendl. Against earthworms - Eudrillus eugeniae.

\begin{tabular}{cccc}
\hline \multirow{2}{*}{ Extract/Drug } & $\begin{array}{c}\text { Concentration } \\
(\mathbf{m g} / \mathbf{m L})\end{array}$ & \multicolumn{2}{c}{ Time in minutes for paralysis/deatha } \\
\cline { 3 - 4 } & & Paralysis & Death \\
\hline Albendazole & 25 & $20.91 \pm 0.50$ & $31.49 \pm 0.82$ \\
& 50 & $15.66 \pm 1.18$ & $28.74 \pm 0.62$ \\
Ethanolic extract & 100 & $12.37 \pm 1.37$ & $22.66 \pm 0.58$ \\
& 25 & $24.86 \pm 0.69$ & $37.73 \pm 0.86$ \\
Aqueous extract & 50 & $20.65 \pm 0.96$ & $33.09 . \pm 0.97$ \\
& 100 & $17.38 \pm 1.02$ & $28.37 \pm 1.36$ \\
& 25 & $29.87 \pm 0.86$ & $45.36 \pm 1.07$ \\
& 50 & $26.22 \pm 1.03$ & $39.36 \pm 0.92$ \\
& 100 & $21.92 \pm 1.22$ & $32.13 \pm 0.94$ \\
\hline
\end{tabular}

a - an average of six readings, values are expressed in mean \pm SEM.

Control worms were alive upto $24 \mathrm{hr}$. of observation

Table 4: Free radical scavenging activity of extract of Solanum xanthocarpum

\begin{tabular}{ccc}
\hline Compd. No.a & $\begin{array}{c}\text { \% Inhibition of DPPH } \\
\text { radicalb }\end{array}$ & $\begin{array}{c}\text { \% Free radical scavenging } \\
\text { activityb }\end{array}$ \\
\hline Standard & & 100 \\
Petroleum ether & 96.23 & 52.66 \\
Chloroform & 50.70 & 46.15 \\
Acetone & 44.41 & 21.08 \\
Ethanol & 20.29 & 52.72 \\
Water & 50.73 & 44.35 \\
\hline
\end{tabular}

${ }^{a}$ Concentration of test compounds was $50 \mathrm{mg} / \mathrm{mL}$, concentration of standard was 0.5 $\mathrm{mg} / \mathrm{mL}$.

${ }^{\mathrm{b}}$ Activity reported at concentration of $50 \mu \mathrm{L}$ of DPPH reagent, values are reported as mean \pm SEM

${ }^{c}$ Standard used was ascorbic acid 
Chhajed, M

Jain, A

Gupta, S

Dubey, I

Shrivastava, AK

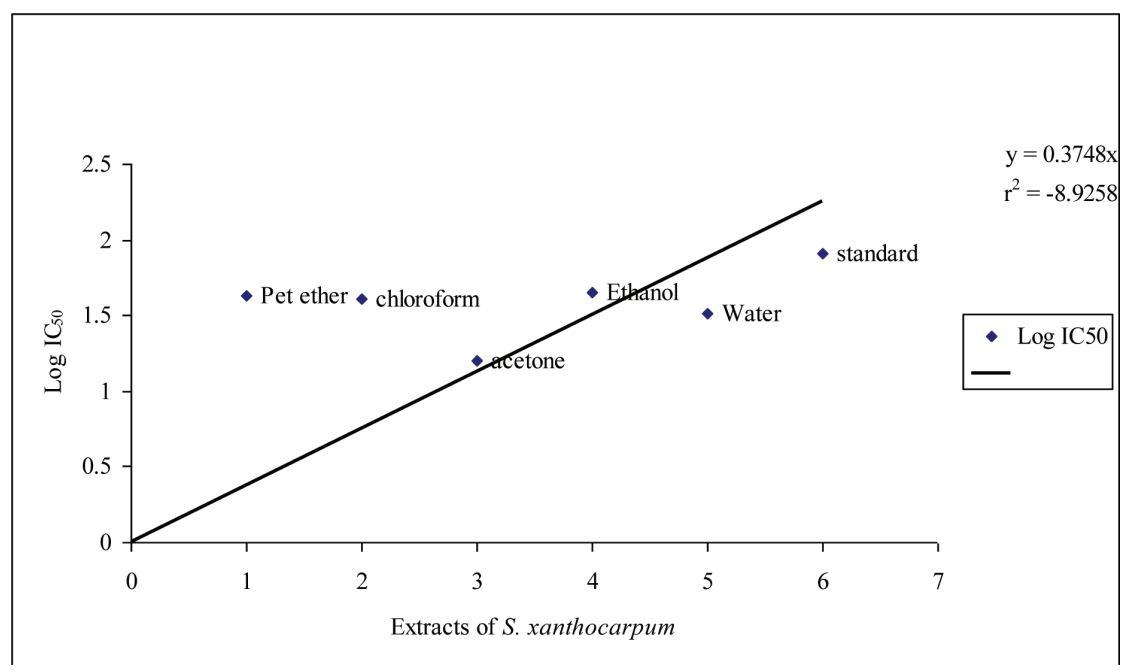

Figure 1: $\log \mathrm{IC}_{50}$ and linear regression.

\section{DISCUSSION}

Antioxidants put efforts to manage the intensity of free radicals earlier than they do oxidative damage with in body. For example, variety of enzymes in the body, such as superoxide dismutase, work with additional compounds to convert free radicals into undamaging molecules. Certain disorders like Cancer, atherosclerosis, cirrhosis, emphysema, and arthritis have been interrelated in the midst of oxidative damage. ${ }^{24}$ Vitamin $\mathrm{C}$ which having antioxidant property which may have preventive action on cataracts and variety of cancers such as cancers of the mouth, esophagus, stomach, and pancreas. ${ }^{25}$ In addition it possibly will avoid the oxidation of LDL cholesterol which may be responsible for lesser the threat of heart ailment.

Geronikaki A, et al. ${ }^{26}$ in 2003 discloses that, the ketonic groups are accountable for scavenging of free radicals. Free Radicals can be defined as atoms or group of atoms which having an unpair electrons and formed by interactions of definite molecules with oxygen. Formerly extremely reactive free radicals produced initiate a chain reaction resembling dominoes. Their major hazard appeared from the damage; they are able to accomplish when they react with significant cellular machinery for instance DNA, or cell membrane. Under the instance cells possibly will work inadequately or die. The body has a security arrangement of antioxidant to avoid free radical damage..$^{27}$ Antioxidants are capable to furnish free radicals, which turn out to be a companion to unpaired electron of preformed free radical, as a consequence eradicate the menace of gene modifications leading to malignancy..$^{28-29}$ 
Certain environmental circumstances, life style factors and standard cellular function throughout body possibly will responsible for the free radical production. These molecules are missing an electron, giving them an electric charge. Free radicals attempt to take an electron from, or give an electron to adjacent molecule, generates a newer free radical from the adjacent molecule, which may lead to neutralization of the charge. The recently formed free radicals, in turn, hunting for an additional molecules and give or take an electron, lay down a series reaction that is able to smash up hundreds of molecules. Antioxidants stop the progress of this series reaction. Several antioxidants are solitary act as free radicals, contribute electrons to steady and counterbalance the hazardous free radicals. Further antioxidants work aligned with the molecules that are able to produce free radicals, wipe out them earlier than they can commence the domino consequence that show the way to oxidative damage. ${ }^{30}$

The current research reveals that the Solanum xanthocarpum encompass pharmacologically dynamic substances such as alkaloids, glycosides, saponins, phenolic compounds and flavonoids, which are accountable for scavenging properties of free radical. The incidence of alkaloids, phenolic compounds and flavonoids in the alcoholic and petroleum ether extract may be responsible for its antioxidant activity than other extracts. So isolation and further analysis of these extracts may reveal, which compound is responsible for its activity and help in further investigation on the mechanism of antioxidant activity of these compounds. Auxiliary researches are in development in our laboratory to assess the other in-vitro models and in-vivo antioxidant prospective of the extracts in different animal models. Phytochemical analyses are also obligatory to ascertain the category of components liable for the thearapeutic activity of this remedial plant and to conclude the significance of the ethnobotanical approach for the evaluating of plants as budding resource of bioactive materials.

The phytochemical screening of extracts was done ${ }^{31}$ and found that sterols, alkaloids, glycosides, tannins, saponins and reducing sugar were present in the plant amongst them alkaloids may responsible for these activities.

\section{ACKNOWLEDGEMENTS}

The authors are highly grateful to Dr. P. Jayaraman, Director, PARC, Chennai for authenticating the plant. The instigators are also thankful to Principal, Sharad Pawar College of Pharmacy, Nagpur for granting needed facilities during the current research.

\section{REFERENCES}

1. Indian Herbal Pharmacopoeia (1998). Ministry of Health \& Family Welfare, Department of Health, Govt. of India, New Delhi. Vol-I. 139.
Phytochemical Investigation and Pharmacological Evaluation of Solanum xanthocarpum Endowed with their potential Activity 
Chhajed, M

Jain, A

Gupta, S

Dubey, I

Shrivastava, AK
2. The Ayurvedic Pharmacopoeia of India (1989). Ministry of Health \& Family Welfare, Department of Health, Government of India, Civil Lines, New Delhi, Vol-I. 1 st edition. 59.

3. The Wealth of India (Raw Material) (1972). Publication and Information Directorate, CSIR, New Delhi. Vol-IX. 393.

4. Govindan, S., Vishwanathan, S., Vijayasekaran, V., Alagappa, R. A Pilot study on the clinical efficacy of Solanum xanthocarpum and Solanum trilobatum in bronchial asthma. J Ethnopharm. 66(2), 205 (1999).

https://doi.org/10.1016/S0378-8741(98)00160-3

5. Bector, N. P. \& Puri, A. S.. Solanum xanthocarpum (Kanthkari) in chronic bronchitis, bronchial asthma, and non-specific unproductive cough (an experimental and pre-clinical co-relatiion). J Assoc physician India. 19(10), 741 (1971).

6. Jain, J. P. A clinical trial of kantkari (Solanum xanthocarpum) in case of tamak swasa (some respiratory diseases). J Res Ayur Siddh. 1, 447-460 (1980).

7. Williamson, E. M (1998). Major Herbs of Ayurveda. 1st edition. New York: Elsevier Health Sciences Publications. 271-273.

8. Kanwar, U., Batla, A., Sanyal, S. N. and Ranga, A. Glycolytic enzyme activities of human and bovine spermatozoa treated in vitro with solasodine. $\mathrm{J}$ Ethnopharmacol. 28(2), 249-254 (1990). https://doi.org/10.1016/0378-8741(90)90035-R

9. Mali, P. C. \& Chaturvedi, M. Antispermatogenic activity of Solanum xanthocarpum (50 percent EtOH-extract) in rats. J phytologic Res. 9(1), 13 (1996).

10. Singh, K. V. and Bansal, S. K. Larvicidal properties of a perennial herb Solanum xanthocarpum against vectors of malaria and dengue/DHF, Current Science. 84(6), 749-751 (2003).

11. Nadkarni, K. M. (1995). Indian Materia Medica2nd edition. Vol-I. Mumbai: Popular Prakashan, 1156.

12. Kirtikar, K. R. \& Basu, B. D. (1988). Indian Medicinal Plants 2nd edition, VolIII, Allahabad: Lalit Mohan Basu, 1759.

13. Kurup, P. N. V. (1977). Handbook of Medicinal Plants, Vol-II. New Delhi: CCRIMH, 48.

14. Karnick, C. R. (1994). Pharmacopoeial Standards of Herbal Plants. New Delhi: Sri Satguru Publications.

15. Sharma, P. C., Yelane, M. P. and Dennis, T. J. (2002). Data base on Medicinal Plants used in Ayurveda Vol-I. New Delhi: Central Council for Research in Ayurveda and Siddha.

16. Ali, SS., Kasoju, N., Luthra, A., Singh, A., Sharanabasava, H., Sahu, A., Bora, U. Indian medicinal herbs as sources of antioxidants. Food Res Int, 41(1), 1-15 (2008). https://doi.org/10.1016/j.foodres.2007.10.001 
17. Keshavamurthy, K. R. \& Yoganarasimhan, S. N. (1990). Flora of Coorg (Kodagu) Karnataka. Bangalore: Vimsat Publishers.

18. Gamble, J. S. (1967). The Flora of the Presidency of Madras, Vol-I. Calcutta: BSI Publishers.

19. Capucino, J. G. \& Sherman, N. (1999). Microbiology a laboratory manual, 4th edition, California: Addison Wesley langman Inc., 263.

20. Gunasekaran, R. Indian J Nat. Pro., 22(1), 11 (2006).

21. Chhajed, M. R., Khedekar, P. B., Mundhey, A. S.. Synthesis and free radical scavenging activity of some 1, 3, 4-thiazole derivative. Indian J Heterocyc chem., 16, 259-262 (2007).

22. Chhajed, M. R., Tomar, G. S., Gautam, S. P., Hariharan, A. G. Phytochemical Investigation and Evaluation of In-vitro Free Radical Scavenging Activity of Flickingeria nodosa Lindl. Indian J Pharm. Edu Res., 42(4), 377-380 (2008).

23. Talesara, G. L., Sharma, R., Nagda, D. P., ARKIVOC. i, 1-12 (2006).

24. Halliwell, B., Gutteridge, J. M. C. Oxygen toxicity, oxygen radicals, transition metals and diseases. Biochem J., 219, 1-4 (1984).

https://doi.org/10.1042/bj2190001

25. D'Mello, P. M., Jadhav, M. A., Jolly, C. I. Free radical scavenging activity of Syzygium cumini and Ficus bengalensis-plants used in Ayurveda for diabetes mellitus. Indian Drugs, 37(11), 518-520 (2000).

26. Geronikaki, A., Litina, D. H., Chatziopoulos, C., Soloupis, G. Synthesis and biological evaluation of new 4,5-disubstituted-thiazolyl amides, derivatives of 4-hydroxy-Piperidine or of 4-N-methyl piperazine. Molecules, 8, 472-479 (2003). https://doi.org/10.3390/80600472

27. Nicholls, D. G., Budd, S. L. Mitochondria and neuronal survival. Physiol Rev, 80, 315-360 (2000). https://doi.org/10.1152/physrev.2000.80.1.315

28. Thomas M. J. The role of free radicals and antioxidants. Nutrition, 16(7-8), 716 (2000). https://doi.org/10.1016/S0899-9007(00)00343-9

29. Patil, S., Jolly, C.I., Narayanan, S. Free radical scavenging activity of Acacia catechu and Rotula aquitica : implication in cancer therapy. Indian Drugs, 40(6), 328-332 (2003).

30. Matill, H. A. Antioxidants. Annu Rev Biochem, 16, 177-192 (1947). https://doi.org/10.1146/annurev.bi.16.070147.001141

31. Harborne, J. B. (1984). Phytochemical method- A guide to modern technique of plant analysis2nd edition. New York: Chapman and Hall, 85.
Phytochemical Investigation and Pharmacological Evaluation of Solanum xanthocarpum Endowed with their potential Activity 